\title{
Kierunki i specyfika współczesnych badań politologicznych w Polsce
}

W rzeczywistości współczesnych przemian kulturowo-cywilizacyjnych szczególną rolę pełni nauka ${ }^{1}$. Jest postrzegana jako główna siła innowacji: ona generuje kierunki rozwoju gospodarczego oraz życia społecznego. Zauważa się przy tym, że następuje dominacja wiedzy teoretycznej, która staje się źródłem wskazywania nowych wyzwań i formułowania strategii i taktyki rozwoju. Nadto w procesach podejmowania decyzji ujawnia się bazowanie na naukowych podstawach ${ }^{2}$.

W obrazie kształtowania się nauki obserwuje się charakterystyczne jej etapy: a) przedindustrialny, b) industrialny, c) postindustrialny (postmodernistyczny). Każdy z nich ujawniał swą odrębność, osadzoną w rzeczywistości rozwoju kulturowo-cywilizacyjnego. W pierwszym z nich trwającym od starożytności do końca XVIII w. definiowano jej powołanie jako działalność mającą na celu rozpoznawanie przyrody, społeczeństwa, człowieka, utożsamiając ją z procesem badawczym, odkrywaniem prawidłowości i zjawisk specyficznych w życiu kulturowym. Badania traktowano jako misję, zwykłe powołanie pojedynczego człowieka, jako szczególne hobby. Nowa rzeczywistość i ich powołanie ujawnia się w sytuacji kształtowania się stosunków przemysłowych. Poszukiwania badawcze zaczęto wiązać z celami utylitarnymi, a nade wszystko włączono w jej przestrzeń poznawczą technikę, która stała się szczególnym wyzwaniem w kształtowaniu rzeczywistości kulturowo-cywilizacyjnej. Zaczęło następować traktowanie nauki jako jednego z wykonywanych zawodów. Ujawniła się wąska specjalizacja. Na początku XX w. wyróżniano około 2 tys. dyscyplin, a w tym

1 J. Muszyński, Społeczeństwo informacyjne. Przewodnik leksykon, Warszawa 2010, s. 115.

2 D. Bell, Nadejście społeczeństwa postindustrialnego, Warszawa 1975, s. 19. 
ponad 1 tys. w przestrzeni nauk ścisłych i technicznych, około 500 - przyrodniczych i medycznych oraz $500 \mathrm{w}$ zakresie badań humanistycznych i społecznych. Wraz z szybkim tempem rozwoju naukowo-technicznego nauka zaczęła nabierać charakteru zespołowego, a w tym wąskiej specjalizacji. W badaniach analiza zaczęła zdobywać pierwszeństwo przed syntezą. Nadto odstępuje się od odwoływania się do „dawnej” wiedzy (stanu badań) na rzecz wskazywania tylko nowych ustaleń poznawczych. Rozwój nauki włączony został w przestrzeń realizacji wyzwań różnych podmiotów kulturowych, a zwłaszcza przemysłu, a tym samym uzależniony został od pozyskania środków finansowych na realizację badań. Nośna stała się w tym względzie konstatacja rosyjskiego fizyka, laureata Nagrody Nobla Piotra Kapicy (1894-1984), „iż na zawsze zginęły szczęśliwe dni wolnej pracy naukowej, przysparzające tyle radości i młodości. Nauka straciła wolność. Nauka stała się siłą produkcyjną, a część jej jest strzeżona w sekrecie"3. Rzeczywistość ta stała się charakterystyczna zwłaszcza w przestrzeni nauk ścisłych i technicznych, mających bezpośredni kontakt z praktyką życia kulturowego. A też ujawniło się faworyzowanie ich przez podmioty życia gospodarczego, jako przynoszące wymierne korzyści, zysk ekonomiczny. Nauki techniczne zaczęto definiować jako paliwo dla życia kulturowego. Pojęcie „badacz” stało się jedną z profesji, którą wykonuje na świecie około 200 mln osób. Wykonują oni zwykle zadania cząstkowe w rozwiązywaniu problemów badawczych.

Osiągnięcia nauki i techniki utorowały drogę do kolejnej fazy rozwoju zwanej cywilizacją informacyjną. W przemyśle ujawnia się automatyzacja, robotyzacja i komputeryzacja. Wysoką pozycję zdobyły przemysły wysokiej techniki: informatyka, telekomunikacja, biotechnologia i chemia wyspecjalizowana. Ujawniły się jednak dysproporcje między rozwojem cywilizacyjnym a rzeczywistością duchowną. W tzw. odwrocie znalazła się wiedza moralna, polityczna, etyczna ${ }^{4}$.

Zauważa się przy tym, że funkcjonują przestarzałe pojęcia: o świecie polityki, bezpieczeństwie, funkcjonowaniu instytucji życia publicznego. Niski jest poziom edukacji o przemianach cywilizacyjnych czy rozpoznawaniu kultury i świadomości politycznej.

Nośne wyzwania ujawniają się w zakresie eliminacji pozostałości życia ludzi w rzeczywistości industrialnej oraz dotyczące wprowadzenia nowych wartości

3 J. Slaus, Dylematy etyczne badań naukowych, „Transformacje” 1993-1994, nr 3-4.

4 A. Peccei, Przyszłość jest w naszych rękach, Warszawa 1987, s. 116. 
kulturowych, zwłaszcza generowanych przez informacyjność. Do istotnych wyzwań w tym względzie należą: a) następstwa społeczno-polityczne rozpadu społeczeństwa masowego kształtowanego w cywilizacji przemysłowej, b) formowanie społeczeństwa zindywidualizowanego (globalnej społeczności obywatelskiej), c) podział społeczeństwa na kreatorów i wykluczonych, d) tworzenie się nowego typu stosunków ekonomicznych (telepraca, gospodarka elektroniczna), e) zastępowanie demokracji liberalnej władzą kreatorów jako działalności mającej na celu walkę o władzę i jej sprawowanie, f) budowa systemu edukacyjnego dostosowanego do potrzeb kształtowania i rozwoju nowej cywilizacji, zapewniającego kształcenie ustawiczne przy wykorzystaniu narzędzi i mechanizmów informatycznych, g) gwarantowanie dostępu do kultury według indywidualnych zainteresowań ludzi.

Zauważa się przy tym, że marginalizowanie nauk humanistycznych i społecznych, m.in. w przestrzeni finansowej powoduje narastanie zagrożeń, wynikających z rozwoju naukowo-technicznego oraz nie podejmuje się istotnych działań na rzecz zmiany tej sytuacji. Obserwuje się na przykład dewastację środowiska naturalnego, osłabienie więzi społecznych, zmniejszenie kreatywności intelektualnej, przeciążenie nadmiarem informacji, degradację rodzimej kultury poprzez narzucenie za pośrednictwem środków masowego przekazu obcych systemów kulturowych, norm, symboli i instytucji ${ }^{5}$.

Kierunki głębokich przemian kulturowych od lat 60 . XX w. zaczęto określać postmodernizmem (ponowoczesnością). Wtedy filozof francuski Jean Francois Lyotard (1924-1998) zaprezentował ekspertyzę dotyczącą rozwoju nowoczesnej nauki i edukacji6. Wskazał, że jej rozumienie jako racjonalności, stabilności, pryncypialności znajduje się w odwrocie. Nowe cechy ją charakteryzujące to: pluralizmy, heterogeniczność, antyfundamentalizm, ambiwalencja, dekonstrukcjonizm, chaos, mieszanie doktryn i stylów, a przede wszystkim podporządkowanie jej zasadom komercji?

Zauważa się, że podstawowym nurtem postmodernizmu jest irracjonalizm, czyli negacja rozumu i intelektualizmu, a promocja funkcji porozumowych,

5 A. Chodubski, Zagrożenia cywilizacyjne współczesnego świata, [w:] Europejski wymiar społeczeństwa energetycznego a ochrona środowiska, red. P. Kwiatkiewicz, R. Szczerbowski, Poznań 2014, s. 39-57.

6 J.F. Lyotard., Kondycja ponowoczesna raport o stanie wiedzy, Warszawa 1997.

7 E. Walewander, Postmodernizm a pedagogika katolicka, Toruń 2014, s. 11. 
intuicyjnych, namiętnościowych i uczuciowych. Promuje się świat jako wielki chaos, w którym ujawnia się tendencje do minimalizowania wszelkich struktur i znaków orientacyjnych.

W ponowoczesności nie neguje się rozumu, ale czyni się go funkcją komputeropodobną. W tej sytuacji prawdziwe wartości zastępują obrazy powierzchniowe, zewnętrzne, często całkowicie ze sobą sprzeczne. W takim ujęciu nauka nie ma obiektywnego i głębszego znaczenia. Każda interpretacja rzeczy i świata jest prawomocna. Odrzuca się metodologię, logikę i naukowy empiryzm ${ }^{8}$.

Postmoderniści proponują odrzucanie kategorii: jedności, całości, uniwersalności. Przekonują, że rzeczywistość jawi się we fragmentach. Stanowi chaotyczny zbiór bez reguł, zasad i praw. Zasadzie ładu i porządku przeciwstawia się w niej chaos.

W kształtującej się przestrzeni naukowej marginalizowana jest wiedza humanistyczna i społeczna, a w tym politologiczna. Utożsamiana jest z wiedzą oraz interpretacją filozoficzną świata, a filozofia wpisuje się w przestrzeń wiedzy, a nie nauki. Pojęcie nauki nierzadko rezerwuje się dla dyscyplin z zakresu nauk przyrodniczych ${ }^{9}$. Wskazuje się przy tym, że rozpoznawanie zachowań ludzkich, a w tym emocji, nie powinno się ujmować w ramy naukowe; zauważa się, że przestrzeń nauk społecznych zorientowana jest na przypominanie postaw, zachowań, wartości. Wskazuje się, że w sferze społecznej nie ma reguł uniwersalnych, a zatem nie ma odkrywczości.

Pod wpływem rozwoju kulturowo-cywilizacyjnego poszerza się zakres rozumienia nauki, a w tym częściowo dopuszcza się do tej przestrzeni nauki humanistyczne i społeczne. Uznaje się, że nauka jest metodą zdobywania wiedzy o świecie ${ }^{10}$.

Naukę dzieli się na przestrzeń teoretyczną i empiryczną. Aczkolwiek nośne staje się odróżnianie nauki od nienauki (wiedzy potocznej). Przestrzeń naukową ujmuje się w formie wąskich dyscyplin naukowych. Przy tym jednak odstępuje się od postrzegania jej wartości autotelicznej na rzecz użyteczności. Jej zadanie sprowadza się do rozwiązywania konkretnych problemów.

Dochodzenie politologii do dyscypliny naukowej odbywało się w przestrzeni dużej kontrowersyjności i nieakceptowania. Utożsamiano ją zwykle

\footnotetext{
8 J. Wulpert, Nienaturalna natura nauki, Gdańsk 1996, s. 124.

9 N. Postman, Technopol. Tryumf techniki nad kulturq, Warszawa 1995.

10 R. Dubnar, Kłopoty z nauka, Gdańsk-Warszawa 1996, s. 29.
} 
$\mathrm{z}$ uprawianiem polityki, a więc zdobywaniem, sprawowaniem i utrzymaniem władzy. Przyjmuje się jednak, że pierwsze symptomy zapowiadające utratę przez filozofię i historię dominującej pozycji w analizowaniu dziejów politycznych oraz osłabienie ich praktycznych aspiracji do bycia dla polityków „przewodniczką w świecie wartości” i „nauczycielką życia” pojawiły się w XIX w. ${ }^{11}$ Pod wpływem myśli pozytywistycznych nośne stawało się przekonanie, że wszelkie dyscypliny naukowe, niezależnie od tego, co jest przedmiotem ich zainteresowań, chcąc podnieść wiarygodność swej wiedzy, muszą podporządkować się naukowym metodom eksplikacji. Przed nauką o polityce stawiano warunki obiektywizmu (eliminowanie wartościowania) oraz poszukiwania systematycznych wyjaśnień badanych zdarzeń. Wyznaczono jej zadanie rozpoznawania i wyjaśnienia mechanizmów zachowania zjawisk politycznych. Zakładano jej powołanie nomotetyczne, uogólniające, poszukujące przede wszystkim względnie trwałych, a nawet ściśle ogólnych reguł, które powinny wyjaśnić obserwowane i opisywane zjawiska polityczne.

Nauka o polityce, stając się przestrzenią ,pozytywną”, traciła przysługujące jej możliwości postrzegania wiedzy jako mądrości. Filozofię polityki uznawano za zbędną w praktyce życia kulturowego. W drugiej połowie XIX w. doszło to tworzenia się instytutalnego, naukowo-edukacyjnego ładu w zakresie nauki o polityce. W 1872 r. utworzona została szkoła nauk politycznych we Francji (Ecole libre des sciences politiques), a w Wielkiej Brytanii założono w $1895 \mathrm{r}$. London School of Economics and Political Sciences. Wtedy też powstały uczelnie politologiczne w Stanach Zjednoczonych Ameryki. W tworzących się ośrodkach nauk politycznych podjęto działania w zakresie określenia granic własnego przedmiotu oraz odrębności metodologicznej. W polskiej przestrzeni kulturowej ujawnia się zainteresowanie, $w$ tym instytucjonalne, edukacją polityczną od czasów nowożytnych. Jako odrębna dyscyplina powstała na początku XX w. W 1902 r. utworzono we Lwowie Szkołę Nauk Politycznych, a w 1911 r. na Uniwersytecie Jagiellońskim Polską Szkołę Nauk Politycznych, wkrótce też powstały placówki nauk politycznych w Warszawie, Wilnie, Łodzi, Poznaniu.

Po I wojnie światowej na tworzących się uczelniach w Polsce upowszechniono wiedzę z zakresu nauk politycznych. Głównie realizowano wyzwanie edukacji politologicznej jako przedmiot dodatkowy na studiach prawnych,

11 N. Krauz-Mozer, P. Borowiec, P. Ścigaj, Kim jesteś politologu. Historia i stan dyscypliny w Polsce, t. I, Kraków 2011, s. 18-21. 
dostarczającego wiedzy o faktach, zdarzeniach z życia politycznego. Istotne ogniwo w rozwoju dyscypliny wiązało się z przygotowywaniem encyklopedii, tj. w 1925 r. Małej encyklopedii politycznej, od 1926 r. Wspótczesnej encyklopedii politycznej; w latach 1936-1939 Encyklopedii nauk politycznych. Zagadnień społecznych, politycznych i gospodarczych.

Po II wojnie światowej kształcenie politologiczne wiązało się z wyzwaniami ideologiczno-politycznymi ${ }^{12}$. Nowa rzeczywistość w rozwoju dyscypliny nastąpiła po 1989 r. w sytuacji przemian ustrojowych. Odrzucono model prowadzonych badań w zakresie badań zjawisk i procesów politycznych, a w tym wartość opisów i eksplantacji rzeczywistości politycznej oraz przestrzeń teoretyczno-metodologiczną. Poddano reorganizacji ład instytucjonalny edukacji z zakresu nauk politycznych. Przed politologią postawiono nowe zadania - tj. głównie dostarczania obiektywnych opisów rzeczywistości politycznej, zdefiniowania na nowo świadomości badań teoretycznych i metodologicznych ${ }^{13}$. W końcu lat 90. ujawniła się swoista „moda na politologię”. Nastąpiło zainteresowanie studiami tej dyscypliny oraz jej tzw. subdyscyplin. W ślad za tym zaczęto tworzyć placówki edukacji politologicznej. Potrzeby kadrowe ujawniły woluntaryzm, tj. za politologów zaczęli uznawać się przedstawiciele różnych dyscyplin naukowych, a w tym nawet reprezentanci nauk ścisłych (fizycy, matematycy, przyrodnicy). Ujawniali przy tym zainteresowanie prezentacją swych opinii w środkach masowego przekazu. Podejmowali się uzasadniania oficjalnej polityki władzy, oceny reform systemu politycznego, rzeczywistości międzynarodowej, a w tym państwa polskiego z różnymi podmiotami przestrzeni międzynarodowej. Starali się wypełniać miejsce ideologiczno-polityczne, kształtowane w okresie PRL, tj. wpisując się w tzw. syndrom politologii służalczej. W objaśnianiu rzeczywistości ujawniło się posługiwanie się perspektywą potocznego doświadczenia społecznego, komentowanie powierzchowne zjawisk życia kulturowego z pominięciem badań, a w tym empirycznych ${ }^{14}$.

W rzeczywistości przemian ustrojowych ujawnił się problem wolności zakresu kształcenia politologicznego. W tym obszarze znalazły się specjalności:

12 A. Żukowski, Politologia jako dyscyplina naukowa i kierunek kształcenia. Zarys problematyki, Olsztyn 2006.

13 Cz. Mojsiewicz, Rozmowy o polskiej politologii, Toruń 2005, s. 116-120.

14 T. Klementewicz, Spór o model metodologiczny nauki o polityce, Warszawa 1991, s. 11. 
prawnicza, filozoficzna, socjologiczna, dziennikarska, administracyjna, stosunki międzynarodowe, a pomijano przedmioty tzw. rdzenia politologicznego, tj. teorii polityki, myśli politycznej, systemów politycznych, partii i systemów partyjnych. Pewna zmiana w tej rzeczywistości nastąpiła w latach 2001-2002. Określono wtedy warunki, jakie musi spełniać uczelnia, by móc prowadzić kierunki studiów, i standardy nauczania na poszczególnych studiach oraz poziomów kształcenia wraz z określeniem sylwetki absolwenta.

Przedmiot badań i edukacji politycznej określono jako: 1) metodologię badań politologicznych, 2) teorię polityki, 3) myśl polityczną, 4) naukę o państwie i polityce, 5) zarządzanie i komunikowanie społeczne, 6) systemy i instytucje polityczne, 7) partie i systemy partyjne, 8) politykę społeczną i gospodarczą, 9) stosunki międzynarodowe, 10) globalizację i lokalizm w życiu politycznym ${ }^{15}$. Przyjęto, że zadaniem politologii jest kompleksowe ujmowanie badanych zagadnień w ich wzajemnych uwarunkowaniach, wskazywanie na powiązania wewnętrzne podsystemów i między nimi, a także w całokształcie systemu politycznego, który jest przedmiotem analizy. W badaniach politologicznych ważnym wyzwaniem jest uwzględnianie ustawiczne zmieniającej się rzeczywistości w różnego rodzaju powiązaniach, poczynając od stosunków prostych, przechodząc do coraz bardziej skomplikowanych - dochodząc w końcowym rezultacie do próby oceny całości funkcjonowania systemów politycznych, z uwzględnieniem powiązań międzynarodowych i polityki w skali światowej.

W 2011 r. nastąpiły kolejne zmiany w edukacji politologicznej. Określone zostały one przez Krajowe Ramy Kwalifikacji dla Szkolnictwa Wyższego, które sytuują się w Europejskich Ramach Kwalifikacji ${ }^{16}$. Wprowadzone zostały one do praktyki akademickiej w 2012 r. Ich nośność polega na określeniu efektów kształcenia, tj. zdobywanego zasobu wiedzy, umiejętności i kompetencji społecznych uzyskiwanych w procesie kształcenia przez jednostkę edukacyjną.

Krajowe Ramy Kwalifikacji w istotnej mierze wyznaczają nowe kierunki uprawiania politologii. Dyscyplina wyłączona jest z obszaru nauk humanistycznych a włączona do nauk społecznych. Usytuowanie to wiąże ją z innymi dyscyplinami należącymi do nauk społecznych. Kształcenie musi być

15 A. Chodubski, Wstęp do badań metodologicznych, Gdańsk 2013, s. 33.

16 Autonomia programowa uczelni. Ramy kwalifikacji dla szkolnictwa wyższego, red. E. Chmielecka, Warszawa 2011. 
z nimi skorelowane. Efekty kształcenia dla obszaru nauk społecznych koncentrują się wokół pojęcia instytucji społecznych, miejscem w systemie relacji społecznych, związkami z otoczeniem społecznym i innymi instytucjami, więziami społecznymi, rolą człowieka oraz sposobami ich badania ${ }^{17}$. Regulacja ta powoduje uwolnienie nazewnictwa oraz treści kierunkowych. W tej sytuacji dotychczasowy tzw. rdzeń politologiczny mogą zastąpić różne przedmioty sytuujące się w przestrzeni nauk społecznych. Wyłączenie politologii z obszaru nauk humanistycznych oddala ją od rozpoznawania tzw. miękkiej przestrzeni życia kulturowego, m.in. świata wartości, symboli. Ujawnia się tu odejście od tradycji, a w tym od dotychczasowego obszaru przedmiotowego oraz metodologii. Przy tym ważne ogniwo zmian wiąże się ze sferą efektywności kształcenia, co z kolei łączy się z rzeczywistością rynkową. Przedmiotowość edukacji staje się uzależniona od popytu na wąską specjalizację na rynku pracy. W tej sytuacji odchodzi się od holistycznego uprawiania dyscypliny, a przede wszystkim sprowadzenia do rozdrobnienia specjalizacyjnego politologii. Konsekwencją czego jest odchodzenie do tradycyjnych wzorów uprawiania politologii.

Nowa rzeczywistość uprawiania politologii postrzegana jest jako kryzys w rozwoju dyscypliny. Jej przestrzeń badawcza jest przekształcona $\mathrm{w}$ „spokrewnione dyscypliny" z obszaru nauk społecznych. Odchodzenie od holistycznego uprawiania nauki o polityce powoduje rozkład dyscypliny. Powszechnie zauważa się, że w rozwoju dyscyplin naukowych siłą budującą jest integracja, a nie dezintegracja.

W kształtującym się nowym porządku uprawiania politologii nośną kwestią staje się stosunek do tradycji, do dziedzictwa przeszłości. Wpływa na to orientacja odrzucająca tradycjonalizm, ujawnia się niechęć do wszystkiego, co jest „stare” w życiu kulturowym, a w tym w przestrzeni politycznej. W tej sytuacji zauważa się, że politologia staje się dyscypliną niedookreśloną; "gubione” jest powołanie tożsamościowe. Odrzuca się jej pytania o przeszłość (w tym o zakres przedmiotowy) nie precyzuje wspólnego obszaru stricte politologicznego, a sytuuje w szerokiej przestrzeni nauk społecznych, jak też nie definiuje ich predykatywności.

17 Rozporządzenie Ministra Nauki i Szkolnictwa Wyższego w sprawie Krajowych Ram Kwalifikacji dla Szkolnictwa Wyższego z dnia 2 listopada 2011 r., Dz.U. 2011, nr 253, poz. 1520 . 
W nowym definiowaniu politologii podkreśla się jej pluralizm. Powoduje on odchodzenie do ściśle określa nych ram badawczych i edukacyjnych, pogłębianych analiz danej rzeczywistości politycznej na rzecz wpisywania jej w różne konteksty przestrzeni nauk społecznych. Nie są w tej sytuacji wyraźnie definiowane założenia teoretyczne. Zastępują je różnorodne wizje początkowe, perspektywy epistemologiczne. Ujawnia się tendencja do niewydzielania wyraźnych całości różnych dyscyplin w ramach nauk społecznych ${ }^{18}$.

W rozpoznawaniu danej rzeczywistości politycznej ujawnia się tendencja do wąskiej analizy aspektów, a minimalizowane całościowego oglądu zjawisk sytuujących się w szerokiej przestrzeni kulturowo-cywilizacyjnej. Wskazuje się przy tym jednak na wielokierunkowość badań, jakie powinny realizować zespoły badaczy, którym przypisuje się większy obiektywizm poznawczy, co jest przeciwstawieniem się oglądowi danej rzeczywistości przez jednego badacza, mogącego prezentować duży subiektywizm w eksplantacji życia kulturowego, a w tym politycznego.

Tradycyjny zakres badań politologicznych ulega podziałom na nowe specjalności, które pozostają w luźnym związku z badaniami stricte dotyczącymi polityki. W tej sytuacji renesans zainteresowania edukacją politologiczną znalazł się w odwrocie, a nawet następuje jego upadek.

Podział politologii na wąskie specjalności uzasadnia się potrzebami rynku pracy i rozpoznawania doraźnych zjawisk życia kulturowego, a w tym politycznego. W ślad za tym ujawniają się nowe kierunki badań w zakresie różnych specjalizacji. W tej sytuacji następuje rozkład tradycyjnej przestrzeni badawczej. Następuje przy tym oddalenie się od powołania teoretyczno-metodologicznego na rzecz doraźnego komentowania rzeczywistości politycznej, którą powoduje wyzwanie poprawności politycznej. Obserwuje się przy tym, że coraz mniej doświadczenia dziedzictwa przeszłości jest wykorzystywane w generowaniu teraźniejszości oraz kształtowaniu przyszłości.

W uprawianiu politologii obserwuje się zjawisko tzw. obsesji metodologicznej. Z jednej strony ujawnia się utyskiwanie na słabość dyscypliny w zakresie posługiwania się odrębnością metod i technik badawczych, z drugiej zaś obserwuje się niechęć do posługiwania się własnymi instrumentami badawczymi

18 J. Niżnik, Przedmiot poznania w naukach społecznych, Warszawa 1979, s. 27. 
sytuującymi się w tzw. metodzie politologicznej ${ }^{19}$. Odrębność ta zawiera się w posługiwaniu się określonymi zasadami pozyskiwania informacji o danej rzeczywistości, jej definiowaniu, systematyzacji, objaśnianiu i interpretacji. Obecnie zauważa się, że kwestie te pozostają w sferze hasłowości, „pouczeń metapoprawnościowych o rozpoznawaniu rzeczywistości politycznej”, a wyzwania poznawcze stają się powierzchowne, warstwa predyktywna wyrażająca się w formie komentarzy, generowana w istotnej mierze przez poprawność polityczną, zwykle nie sprawdza się w praktyce kulturowej, a w tym w życiu politycznym. Krytyczny ogląd tej rzeczywistości powoduje, że poddaje się w wątpliwość, czy politologia jest dziedziną naukową? ${ }^{20}$ Krytyczny ogląd politologii ujawnia przestrzeń wiązania się jej z mass mediami. Wiedza o polityce jest prezentowana powierzchownie, potocznie, zgodnie z oczekiwaniami określonych sił politycznych ${ }^{21}$.

Dyscyplina jest ukierunkowywana na internacjonalizację, na odwoływanie się do tzw. standardów światowych. W polskiej praktyce jest to w pełni urzeczywistniane. W światowym wymiarze wskazuje się na: a) odwrót od badań wąsko empirycznych na rzecz ujęć teoretycznych, przy tym wiążących teorię z praktyką społeczno-polityczną; b) odchodzenie od statystycznych modeli systemowych na rzecz rozpoznawania życia politycznego pozostającego w toku „stawania się”; c) rozpoznawanie ruchów społecznych, działalności jednostek zaangażowanych w generowanie życia politycznego; d) rozpoznawanie systemów wartości form dyskursu, mentalności zbiorowej, kultury politycznej; e) posługiwanie się metodami badawczymi ukierunkowanymi na interpretację, rozpoznawanie studiów przypadku.

Wśród tematów o szczególnej nośności w badaniach politologicznych są zagadnienia sytuujące się w obszarze interdyscyplinarności. Wśród nich znajdują się: 1) procesy zachodzącej jednocześnie unifikacji i dywersyfikacji życia politycznego, 2) tworzenie się nowego ładu instytucjonalnego, a w tym ujawnianie się możliwości i zagrożeń realizacyjnych; 3) urzeczywistnianie idei demokracji

19 A. Chodubski, O kształtowaniu się metody politologicznej, [w:] Podejścia badawcze i metodologiczne w nauce o polityce, red. B. Krauz-Mozer, P. Ścigaj, Kraków 2013, s. 435-445.

20 A. Heywood, Politologia, Warszawa 2008, rozdz. I.

21 A. Chodubski, Powołanie naukowe a potoczność uprawiania politologii, [w:] Teoretyczne i metodologiczne wyzwania badań politologicznych w Polsce, red. A. Antoszewski i in., Lublin 2009, s. 35-49. 
w społeczeństwie informacyjnym, 4) kształtowanie się nowych form kontaktów międzynarodowych, 5) migracje ludności, w tym rzeczywistość narodowa i etniczna, 6) tworzenie kultury rynkowej (marketingowej), 7) nowe tendencje w zarządzaniu, 8) kształtowanie bezpieczeństwa politycznego, 9) jednostka jako podmiot współczesnego życia kulturowo-cywilizacyjnego, 10) przywództwo polityczne we współczesnym świecie. Tematy te obok powiązań z różnymi ogniwami poznania nauk społecznych sytuują się też w obszarze nauk humanistycznych, zwłaszcza tzw. miękka rzeczywistość kulturowa ${ }^{22}$.

Postrzegając krytycznie stan badań politologicznych w Polsce, zauważa się dominację ujęć opisowych, unikanie formułowania praw naukowych, unikanie stosowania wyjaśnień genetyczno-strukturalnych, genetyczno-funkcjonalnych i systemowych, a obserwuje się rozpoznawanie zjawisk i procesów w ujęciu prawnym. Analizę politologiczną zastępują proste opisy prawne i okołoprawne. W całokształcie zakresu badań politologicznych, a w tym instytucjonalizacji życia politycznego, systemach politycznych, stosunkach międzynarodowych, ujawnia się z dużą siłą objaśnienie stricte prawnicze. Marginalizowane są interpretacje z zakresu nauk społecznych, socjologiczne, psychologiczne, kulturoznawcze, nauki o cywilizacji, a w tym predyktywność 23 . Wyrażana jest przy tym nierzadko opinia, że nie jest możliwe naukowe rozpoznawanie rozwoju polityki.

Kształt uprawiania politologii w istotnej mierze zależy od jej kadr. W ostatnich latach ujawniła się tendencja do powierzania stanowisk organizacyjnych w nauce i życiu akademickim młodym ich adeptom. Często przy tym kryterium w obejmowaniu stanowisk jest zaangażowanie w życie polityczne. W tej sytuacji nastąpiło osłabienie autorytetu mistrza jako miarodajnego twórcy i organizatora życia naukowego, z dużą siłą zjawisko to wystąpiło w obszarze uprawiania politologii. Ujawniło się przy tym też pytanie, czy mistrzami, autorytetami są uczeni gabinetowi, legitymujący się oryginalnymi osiągnięciami, badaniami, czy też jednostki „hałaśliwe”, obecnie w przestrzeni medialnej opowiadające

22 Nauka w Polsce w perspektywie XXI wieku, Komitet Prognoz „Polska w XXI wieku przy Prezydium PAN”, Warszawa 1996, s. 305-306; S.D. Tansey, Nauki polityczne, Poznań 1997; M.G. Roskin i in., Wprowadzenie do nauk politycznych, Poznań 2001; Aspekty metodologiczne oraz teoretyczne w subdyscyplinach politologii, red. Ł. Młyńczyk, B. Nitschke, Toruń 2013.

23 T. Bodio, A. Chodubski, Politologia jako futurologia, [w:] Meandry polityki, red.

B. Kaczmarek, t. 2, Warszawa 2008, s. 343-367. 
się „za czyimś” bądź „przeciwko czemuś”. W przestrzeni tej ujawniają się też zachowania pełne amatorszczyzny. Jednostki nie legitymujące się wykształceniem politologicznym, nie mające też doświadczenia pracy akademickiej tutaj podejmują działania na rzecz świadomego zapomnienia o dotychczasowej tożsamości dyscypliny, definiując się jako budowniczowie „nowej politologii” (zorientowanej na dywersyfikację, pluralizm, doraźność).

Istotne ogniwo w rozwoju politologii stanowią interpretacje cywilizacyjne, zorientowane zwłaszcza na poszukiwanie prawidłowości w zjawiskach i procesach życia społeczno-politycznego ${ }^{24}$. Istotne jest w tym względzie objaśnienie: 1) prawidłowości przemian kulturowo-cywilizacyjnych, generowanych zwłaszcza przez postęp naukowo-techniczny, a w tym przez informacyjność; 2) roli międzynarodowych rozwiązań prawnych w życiu społeczno-politycznym; 3) roli nowoczesnej edukacji w generowaniu rzeczywistości międzynarodowej; 4) istoty społecznego bezpieczeństwa światowego; 5) istoty unifikacji i dywersyfikacji życia kulturowego, a w tym politycznego; 6) zderzania się tradycji i nowoczesności w życiu społeczno-politycznym; 7) synkretyzmu kulturowego w życiu społeczno-politycznym; 8) roli jednostki w generowaniu życia politycznego; 9) form zarządzania politycznego w cywilizacji informacyjnej; 10) tendencji rozwoju życia społeczno-politycznego w rzeczywistości globalnej i lokalnej. Są to wyzwania wymagające refleksji holistycznej, a zatem głębokiej interdyscyplinarnej wiedzy, co mogą urzeczywistniać badacze legitymujący się dużym dorobkiem naukowo-dydaktycznym. W tej sytuacji znajdują się na uboczu zainteresowania młodego pokolenia politologów, dla których nośna jest przede wszystkim orientacja normatywnoprawna, dotycząca funkcjonowania państwa oraz niektórych instytucji politycznych. W wykorzystaniu materiałów źródłowych ujawnia się zwykle odwoływanie do instytucji badania opinii publicznej. W tej sytuacji wykładnię wiedzy, pogłębioną analizą, zastępuje wiedza sondażowa, a w tym opinie ludzi „przypadkowych”. W recepcji intelektualnej powoduje to osłabianie tożsamości politologii jako nauki.

We współczesnych badaniach politologicznych obserwuje się tzw. przyspieszenie poznawcze. Ujawnia się tendencja do prezentowania politycznej rzeczywistości pozostającej w toku stawania się w formie monografii. Pomija się przy

24 A. Chodubski, O aktualnych tendencjach w badaniach politologicznych, [w:] Procesy badawcze i metodologiczne politologii $w$ Polsce, red. A. Chodubski, M.J. Malinowski, Gdańsk 2006, s. 10-25. 
tym wymóg teoretyczny badań humanistycznych, sytuowania rozpoznawczego zjawisk w długim horyzoncie czasowym, jak też okoliczności je generujących i stymulujących. Rozpoznawanie naukowe zastępuje sprawozdawczość, powierzchowność. Zauważa się przy tym, że prowadzenie badań politologicznych bez znajomości i stosowania teorii osłabia tożsamość dyscypliny. W jej uprawianiu niezwykle ważna jest świadomość metodologiczna politologów. Wiedza metodologiczna oznacza znawstwo metod badawczych i systemów naukowych, pozwalające wyrażać i utrwalać zdobycze nauki ${ }^{25}$.

W refleksji uogólniającej można twierdzić, że: 1) zainteresowanie intelektualne polityką datuje się od czasów nowożytnych. Od początku XX w. kształtuje się jej instytucjonalne powołanie jako dyscypliny naukowej; 2) jej przedmiot „polityka” powoduje, że sytuowana jest w okowach zależności od podmiotów życia publicznego; 3) głębokie zmiany w jej tożsamości ujawniają się od lat 90. XX w., co wiąże się z przemianami ustrojowymi w Polsce oraz nowymi powiązaniami międzynarodowymi; 4) obecnie jej oblicze znajduje się w przestrzeni urzeczywistniania idei postmodernizmu; 5) w praktyce kulturowej zderza się w jej uprawianiu tradycja z wzorami ujawniającymi się w naukach społecznych. Osłabiona jest jej odrębność na rzecz integracji z różnymi dyscyplinami nauk społecznych.

\section{Bibliografia}

Aspekty metodologiczne oraz teoretyczne w subdyscyplinach politologii, red. Ł. Młyńczyk, B. Nitschke, Toruń 2013.

Autonomia programowa uczelni. Ramy kwalifikacji dla szkolnictwa wyższego, red. E. Chmielecka, Warszawa 2011.

Bell D., Nadejście społeczeństwa postindustrialnego, Warszawa 1975.

Bodio T., Chodubski A., Politologia jako futurologia, [w:] Meandry polityki, red. B. Kaczmarek, Warszawa 2008.

Chodubski A., O aktualnych tendencjach w badaniach politologicznych, [w:] Procesy badawcze i metodologiczne politologii w Polsce, red. A. Chodubski, M.J. Malinowski, Gdańsk 2006.

25 W. Żebrowski, Badanie polityki. Ogniwa procesu badawczego na studiach politologicznych, Olsztyn 2012, s. 29. 
Chodubski A., O kształtowaniu się metody politologicznej, [w:] Podejścia badawcze i metodologiczne w nauce o polityce, red. B. Krauz-Mozer, P. Ścigaj, Kraków 2013.

Chodubski A., Powołanie naukowe a potoczność uprawiania politologii, [w:] Teoretyczne i metodologiczne wyzwania badań politologicznych w Polsce, red. A. Antoszewski i in., Lublin 2009.

Chodubski A., Wstęp do badań metodologicznych, Gdańsk 2013.

Chodubski A., Zagrożenia cywilizacyjne wspótczesnego świata, [w:] Europejski wymiar społeczeństwa energetycznego a ochrona środowiska, red. P. Kwiatkiewicz, R. Szczerbowski, Poznań 2014.

Dubnar R., Kłopoty z nauka, Gdańsk-Warszawa 1996.

Heywood A., Politologia, Warszawa 2008.

Klementewicz T., Spór o model metodologiczny nauki o polityce, Warszawa 1991.

Krauz-Mozer N., Borowiec P., Ścigaj P., Kim jesteś politologu. Historia i stan dyscypliny w Polsce, t. I, Kraków 2011.

Lyotard J. F., Kondycja ponowoczesna raport o stanie wiedzy, Warszawa 1997. Mojsiewicz Cz., Rozmowy o polskiej politologii, Torun 2005.

Muszyński J., Społeczeństwo informacyjne. Przewodnik leksykon, Warszawa 2010. Nauka w Polsce w perspektywie XXI wieku, Komitet Prognoz „Polska w XXI wieku przy Prezydium PAN”, Warszawa 1996.

Niżnik J., Przedmiot poznania w naukach społecznych, Warszawa 1979.

Peccei A., Przyszłość jest w naszych rękach, Warszawa 1987.

Postman N., Technopol. Tryumf techniki nad kultura, Warszawa 1995.

Roskin M.G. i in., Wprowadzenie do nauk politycznych, Poznań 2001.

Rozporządzenie Ministra Nauki i Szkolnictwa Wyższego w sprawie Krajowych Ram Kwalifikacji dla Szkolnictwa Wyższego z dnia 2 listopada 2011 r., Dz.U. 2011, nr 253, poz. 1520.

Slaus J., Dylematy etyczne badań naukowych, „Transformacje” 1993-1994, nr 3-4.

Tansey S.D., Nauki polityczne, Poznań 1997.

Walewander E., Postmodernizm a pedagogika katolicka, Toruń 2014.

Wulpert J., Nienaturalna natura nauki, Gdańsk 1996.

Żebrowski W., Badanie polityki. Ogniwa procesu badawczego na studiach politologicznych, Olsztyn 2012.

Żukowski A., Politologia jako dyscyplina naukowa i kierunek kształcenia. Zarys problematyki, Olsztyn 2006. 


\section{Streszczenie}

W studium wskazuje się, że zainteresowanie intelektualne polityką datuje się od czasów nowożytnych. Od początku XX w. kształtuje się jej instytucjonalne powołanie jako dyscypliny naukowej. Jej przedmiot „polityka” powoduje, że sytuowana jest w okowach zależności od podmiotów życia publicznego. Głębokie zmiany w jej tożsamości ujawniają się od lat 90. XX w., co wiąże się z przemianami ustrojowymi w Polsce oraz nowymi powiązaniami międzynarodowymi. Obecnie jej oblicze znajduje się w przestrzeni urzeczywistniania idei postmodernizmu. W praktyce kulturowej zderza się w jej uprawianiu tradycja z wzorami ujawniającymi się w naukach społecznych. Osłabiona jest jej odrębność na rzecz integracji z różnymi dyscyplinami nauk społecznych.

Stowa kluczowe: politologia, nauka, zakres badawczy, postmodernizm, świadomość politologiczna

\section{Abstract}

The study indicates that intellectual interest in politics dates back to modern era. Since the beginning of the twentieth century, politics has been constituted as a scientific discipline. However, it is clear that its subject of research concerns issues being in the dependency on subjects of public life. Deep changes in its identity have been revealing since the 1990s. It has been connected with the political changes in Poland and new international links after the collapse of communism. Nowadays, its face is in the space of implementation of the idea of postmodernism. In cultural practice there is a clash of tradition with the patterns emerging in the social sciences. Hence, its own distinctiveness is diminished by ties with other social science disciplines.

Keywords: politics, political science, science, the scope of research, postmodernism, political consciousness. 